\title{
SKEMA PENGIRIMAN SUSU DENGAN MENGGUNAKAN GRAF
}

\author{
Riski Nur Istiqomah Dinnullah \\ Prodi Pendidikan Matematika, FST, Universitas Kanjuruhan Malang, Jl. S. Supriyadi 48 \\ Malang \\ ky2_zahra@unikama.ac.id
}

\begin{abstract}
Abstrak
Tujuan dari penelitian ini adalah mengkontruksikan model pengiriman susu. Penerapan graf digunakan untuk mengoptimalkan pengiriman susu sapi ke outlet dan industri pengolahan susu. Data yang digunakan adalah data numerik dan data deskripsi jadwal dan tempat pengiriman susu pada Koperasi Susu SAE Pujon yang dilakukan pada Bulan Mei 2017. Data yang dikumpulkan kemudian dianalisis dengan menggunakan graf. Hasil penelitian menunjukkan bahwa terdapat 2 truk yang digunakan untuk mengirimkan susu pada 6 outlet di area Malang dan Batu. Dari hasil simulasi diperoleh bahwa terdapat 9 model simulasi pada pengiriman susu yang dapat dilakukan agar tidak ada outlet yang terlewati.
\end{abstract}

Kata Kunci: Model Pengiriman Susu, Graf

\section{PENDAHULUAN}

Susu sapi menjadi susu yang paling banyak dikonsumsi oleh masyarakat di Indonesia. Selain harganya relatif murah dan mudah diperoleh, susu sapi mempunyai nilai gizi yang sangat tinggi (Sutrisno, dkk, 2015). Selain dapat dikonsumsi secara langsung, susu menjadi bahan dasar untuk industri pengolahan susu. Dalam aktivitas ekonomi, susu memiliki potensi yang besar untuk mengembangkan perekonomian nasional di masa depan (Dinnullah dan Fayeldi, 2016).

Masyarakat menangkap peluang usaha ini dalam berbagai bentuk. Ada beberapa peternak yang menjadi pengumpul susu sapi untuk selanjutnya di jual ke pengumpul yang lebih besar seperti Koperasi Susu Sae Pujon. Susu sapi yang dikumpulkan ada yang dijual secara eceran maupun dimanfaatkan sebagai bahan baku suatu produk tertentu seperti yogurt dan susu pasteurisasi. Selain itu, susu tersebut juga dikirim ke beberapa industri pengolahan susu sapi yang ada di Jawa Timur, antara lain PT. Nestle yang ada di Kejayan dan PT. Indolakto di Purwosari Kabupaten Pasuruan.

Dalam proses pegiriman susu dibutuhkan ketepatan waktu sesuai dengan permintaan para distributor atau konsumen. Oleh karena itu, untuk mencegah 
keterlambatan, dibutuhkan suatu metode yang dapat digunakan untuk membuat model pendistribusian susu.

Pendekatan Matematika sering digunakan untuk menyelesaikan berbagai permasalahan (Dinnullah \& Fayeldi, 2016). Terutama pada masalah pengiriman banrang, aplikasi dalam bidang matematika yang banyak digunakan adalah teori graf .

Teori graf merupakan cabang ilmu matematika yang menarik dan banyak dikembangkan. Dengan mengkaji dan menganalisa model atau rumusan dapat diperlihatkan peranan dan kegunaan teori graf dalam memecahkan berbagai macam permasalahan. Permasalahan yang dirumuskan dengan teori graf dibuat sederhana, yaitu diambil aspek-aspek yang diperlukan dan dibuang aspek-aspek lainnya. Selain itu graf dapat juga digunakan untuk merepresentasikan obyekobyek diskrit dan hubungannya antara obyek-obyek tersebut (Roza, Narwen, dan Zulakmal, 2014). Model-model yang ada pada teori graf berguna untuk aplikasi yang luas, seperti masalah dalam jaringan komunikasi, transportasi, ilmu komputer, riset operasi, dan lain sebagainya (Listiyana dan Hariyanto, 2008).

Berdasarkan definisi, graf sederhana

$G$ terdiri dari himpunan tak kosong dan berhingga $V(G)$ dari elemen-elemen yang disebut titik (atau node) dan himpunan berhingga $E(G)$ dari pasangan tak berurutan $V(G)$ yang disebut sisi (Murugan dan Esther, 2014). $V(G)$ adalah himpunan titik dan $E(G)$ adalah himpunan sisi dari $\mathrm{G}$. Sebuah sisi $\{v, w\}$ dikatakan terhubung dengan titik $\mathrm{v}$ dan $\mathrm{w}$ dan biasanya ditulis vw (Wilson, 1998). Sedangkan banyaknya unsur di $\mathrm{V}$ disebut order dari $\mathrm{G}$ dan dilambangkan dengan $p(G)$ dan banyaknya unsur di $E$ disebut size dari $G$ dan dilambangkan dengan $q(G)$. Jika graf yang dibicarakan hanya graf $\mathrm{G}$, maka order dan ukuran dari $G$ tersebut cukup ditulis dengan $\mathrm{p}$ dan $\mathrm{q}$ (Chartrand dan Lesniak, 1986).

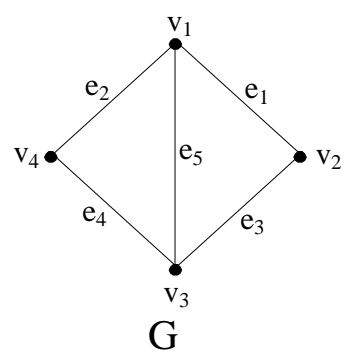

\section{Gambar 1. Graf G}

Graf $\mathrm{G}$ mempunyai 4 titik sehingga order $\mathrm{G}$ adalah $p(G)=4$, sedangkan garis dari graf $G$ adalah 5 sehingga size $G$ adalah $q(G)=5$.

Himpunan titik dari graf $\mathrm{G}$ adalah

$$
V=\left\{v_{1}, v_{2}, v_{3}, v_{4}\right\} \text {. }
$$

Sementara, himpunan sisi atau garis dari $G$ adalah

$$
\begin{aligned}
E & =\left\{e_{1}, e_{2}, e_{3}, e_{4}, e_{5}\right\} \\
E & =\left\{v_{1} v_{2}, v_{1} v_{4}, v_{2} v_{3}, v_{3} v_{4}, v_{1} v_{3}\right\}
\end{aligned}
$$

Penelitian yang berkaitan dengan Graf telah dilakukan oleh Miftahurrahmah (2016) untuk mengetahui bagaimana pengaturan durasi lampu lalu lintas untuk mengatasi kemacetan di persimpangan jalan raya. Selain itu, penerapan graf juga telah dilakukan oleh Kusmira dan Taufiqurrochman (2017) yang membahas tentang pemanfaatan aplikasi graf pada pembuatan jalur angkot 05 di Tasikmalaya dengan menggunakan metode persoalan tukang pos cina dimana lintasan dan sirkuit yang dipakai adalah lintasan dan sirkuit euler.

Dalam penelitian ini, Graf digunakan untuk mengkonstruksi model pengiriman susu sapi dari produsen ke distributor. Sehingga proses pengiriman susu dapat optimal dilakukan dan dapat meminimalisir adanya outlet yang tidak terkunjungi serta menambah kualitas pelayanan produsen 
FIBONACCI : Jurnal Pendidikan Matematika dan Matematika. Vol. 4 (2), pp: 123-130.

terhadap distributor maupun industri

pegolahan susu.

\section{METODE PENELITIAN}

Penelitian ini merupakan penelitian yang bertujuan untuk melihat keoptimalan pengiriman susu dengan menggunakan aplikasi graf. Oleh karena itu metode yang digunakan adalah metode penelitian kualitatif dengan jenis deskriptif. Sementara, objek dalam penelitian ini adalah Koperasi Susu Sae Pujon yang bertempat di Jl. Brigjend Abdul Manan Wijaya, Desa Pujon Lor, Kecamatan Pujon, Kabupaten Malang, Jawa Timur.

\section{Sumber dan Teknik Pengumpulan Data}

Data pada penelitian ini digunakan 2 jenis data yaitu (1) data numerik dan (2) data deskripsi. Data numerik digunakan dalam proses pengiriman susu dengan menggunakan graf. Sedangkan data deskripsi digunakan untuk memperkuat serta justifikasi analisis dan kesimpulan yang akan ditarik dari hasil penerapan graf. Data yang akan digunakan dalam penelitian ini adalah data pada bulan Mei 2017. Berikut ini disajikan rincian data dan sumber data yang digunakan pada penelitian ini.

Tabel 1. Data dan Sumber Data Penelitian

\begin{tabular}{|c|c|c|}
\hline $\begin{array}{l}\text { Jenis } \\
\text { Data }\end{array}$ & Data & $\begin{array}{c}\text { Sumber } \\
\text { Data }\end{array}$ \\
\hline \multirow[t]{3}{*}{$\begin{array}{l}\text { Data } \\
\text { numerik }\end{array}$} & $\begin{array}{l}\text { Daftar outlet } \\
\text { pengiriman }\end{array}$ & \multirow[t]{3}{*}{$\begin{array}{l}\text { Kop SAE } \\
\text { Pujon }\end{array}$} \\
\hline & $\begin{array}{l}\text { Daftar } \\
\text { permintaan dan } \\
\text { batas waktu }\end{array}$ & \\
\hline & $\begin{array}{lr}\text { Jumlah } & \text { dan } \\
\text { daya } & \text { muat } \\
\text { trasportasi } & \\
\end{array}$ & \\
\hline $\begin{array}{l}\text { Data } \\
\text { deskripsi }\end{array}$ & $\begin{array}{l}\text { Jadwal } \\
\text { pengiriman } \\
\text { pabrik dalam } 1\end{array}$ & $\begin{array}{l}\text { Kop SAE } \\
\text { Pujon }\end{array}$ \\
\hline
\end{tabular}

\begin{tabular}{|c|c|c|}
\hline $\begin{array}{l}\text { Jenis } \\
\text { Data }\end{array}$ & Data & $\begin{array}{c}\text { Sumber } \\
\text { Data }\end{array}$ \\
\hline & bulan & \\
\hline & $\begin{array}{l}\text { Metode/teknik } \\
\text { penyusunan } \\
\text { jadwal } \\
\text { pengiriman }\end{array}$ & \\
\hline & $\begin{array}{l}\text { Relevansi solusi } \\
\text { yang } \\
\text { ditawarkan } \\
\text { dengan kondisi } \\
\text { praktik }\end{array}$ & $\begin{array}{l}\text { Kop SAE } \\
\text { Pujon/driver }\end{array}$ \\
\hline & $\begin{array}{l}\text { Kondisi } \\
\text { lapangan }\end{array}$ & \\
\hline & $\begin{array}{l}\text { Costumer } \\
\text { satisfaction } \\
\text { pada ketepatan } \\
\text { waktu } \\
\text { pengiriman }\end{array}$ & $\begin{array}{l}\text { Outlet susu } \\
\text { sapi/IPS } \\
\text { (Industri } \\
\text { Pengolah } \\
\text { Susu) }\end{array}$ \\
\hline
\end{tabular}

Teknik pengumpulan data yang dilakukan pada penelitian ini meliputi (1) wawancara, (2) observasi lapangan, dan (3) dokumentasi. Wawancara dilakukan untuk memperoleh data deskripsi dari praktikan pengiriman antara lain manajemen pabrik, sopir, dan pemilik outlet. Observasi lapangan yang pada penelitian ini berupa kegiatan peneliti mengikuti proses pengambilan keputusan penjadwalan oleh pihak pabrik susu. Sementara, teknik dokumentasi meliputi pengambilan gambar, rekam suara, dan catatan lapangan.

\section{Prosedur Analisis Data}

Prosedur analisis data yang dilakukan pada penelitian ini disesuiakan dengan metode penelitian yaitu metode kualitatif. Analisis data dibagi menjadi 4 bagian yaitu (1) reduksi data, (2) display data, (3) penarikan kesimpulan, dan (4) verifikasi. Reduksi data dilakukan untuk mengeliminasi data-data pencilan yang dimungkinkan muncul karena suatu kondisi khusus. data yang telah melalui proses reduksi disajikan dalam bentuk tabel, 
grafik, maupun gambar. Pada langkah selanjutnya, menerapkan graf pada proses pengiriman susu dari data dan informasi yang disajikan. Penarikan kesimpulan dilakukan berdasarkan hasil pelaksanaan algoritma dan diverifikasi dengan cara membandingkan hasil algoritma dengan penjadwalan yang selama ini digunakan oleh pabrik. selain itu, dilakukan juga justifikasi relevansi hasil dengan kondisi lapangan oleh praktikan pengiriman. prosedur penelitian ini akan dilakukan secara berulang hingga diputuskan bahwa data dan kesimpulan yang didapat telah cukup. secara keseluruhan prosedur penelitian dapat dilihat pada skema berikut ini.

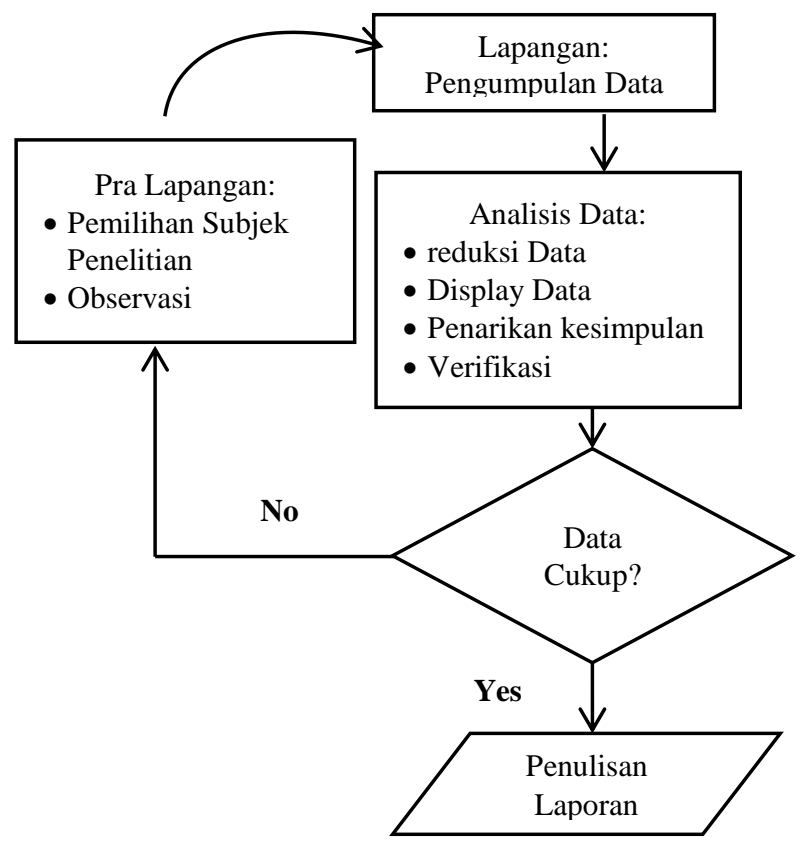

Gambar 2. Skema Prosedur Penelitian

\section{Bagan Metodologi Penelitian}

Bagan Metodologi Penelitian diberikan pada gambar 3 berikut ini

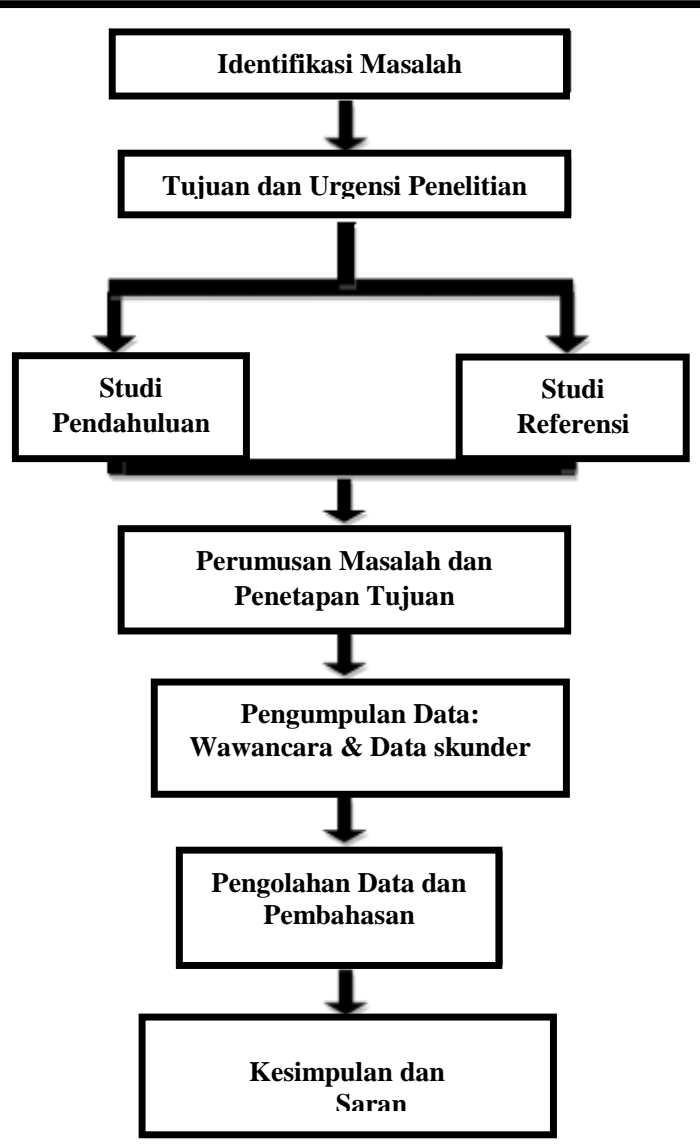

Gambar 3. Bagan Penelitian

\section{Model Jalur Pengiriman Susu}

Untuk menganalisis relevansi keoptimalan model pengiriman susu ini, maka perlu dibuat model jalur pengirimannya yang dapat dilihat pada gambar 4 berikut ini.

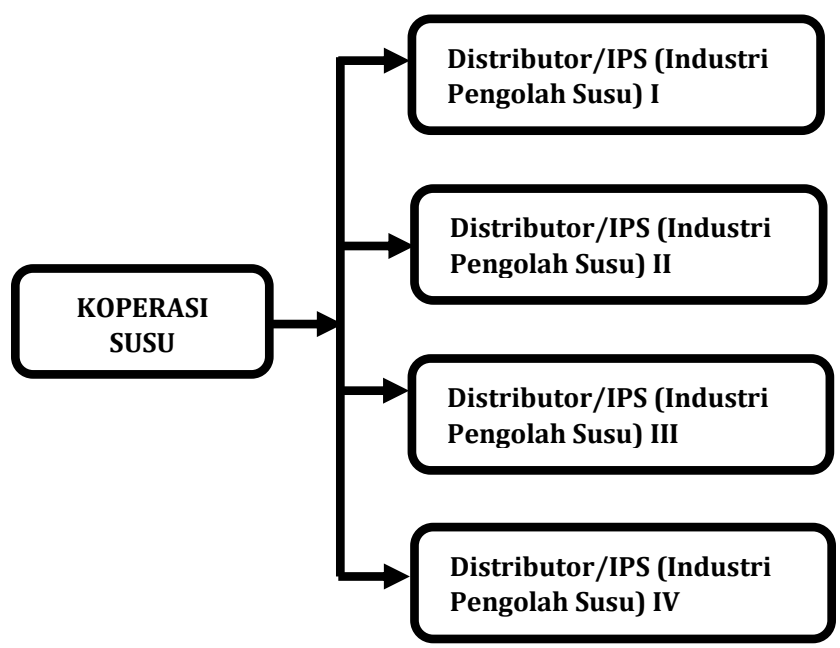

Gambar 4. Model Jalur Pengiriman Susu 
FIBONACCI : Jurnal Pendidikan Matematika dan Matematika. Vol. 4 (2), pp: 123-130.

\section{HASIL DAN PEMBAHASAN}

\section{Data Penelitian}

Pada penelitian ini untuk rute pengiriman dibatasi pada Daerah Malang dan Batu tanpa memperhatikan jarak pengiriman dan pengiriman dilakukan secara acak ke berbagai outlet tersebut. Setiap hari ada 6 outlet di Malang yang dikunjungi dengan menggunakan 2 truk. Outlet-outlet tersebut antara lain Sae Cooperative Pujon, Kedai Susu Segar Malang, Susu Segar Sae Pujon, Milk Cow Pure, H-Q Susu Pujon dan Industri Pengolahan Susu. Untuk banyaknya susu yang dikirim diberikan sebagai berikut.

Tabel 2. Banyaknya Pengiriman Susu

\begin{tabular}{clc}
\hline No & Nama Outlet & $\begin{array}{c}\text { Banyaknya } \\
\text { Pengiriman }\end{array}$ \\
\hline 1 & $\begin{array}{l}\text { Sae Cooperative } \\
\text { Pujon }\end{array}$ & 1 ton \\
\hline 2 & $\begin{array}{l}\text { Kedai Susu } \\
\text { Segar Malang }\end{array}$ & 0,5 ton \\
\hline 3 & $\begin{array}{l}\text { Susu Segar Sae } \\
\text { Pujon }\end{array}$ & 1 ton \\
\hline 4 & Milk Cow Pure & 0,5 ton \\
\hline 5 & H-Q Susu Pujon & 0,5 ton \\
\hline 6 & Industri & 1 ton \\
& Pengolahan Susu \\
\hline & Pengiriman dilaksanakan setiap hari
\end{tabular}
yaitu jam 7.00 WIB atau jam 8.00 WIB dan tidak ada jadwal yang ditentukan untuk masing-masing tempat. Truk yang telah siap akan berangkat terlebih dahulu. Proses pengiriman yang dilakukan secara acak ada beberapa outlet yang terkadang terlewati untuk mendapatkan kiriman susu. Oleh karena itu, diperlukan skema pengiriman susu yang efektif dan efisien, sehingga terjadi ketepatan waktu serta pengiriman dapat dilakukan ke semua outlet tanpa terlewati.
Sebelum graf diterapkan dalam masalah pengiriman susu ini, terlebih dahulu mempresentasikan komponenkomponen pengiriman susu ke dalam graf. Adapun penggambaran banyaknya truk pengirim susu dan banyaknya outlet susu dapat dilihat pada gambar berikut ini:

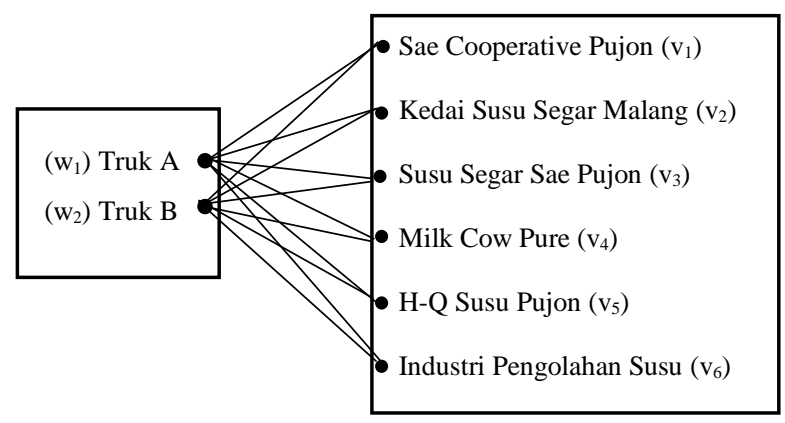

Gambar 5. Banyaknya Truk Pengirim Susu dan Outlet Susu

Dari gambar 5, maka dapat diketahui himpunan titik dari graf antara lain $V=\left\{v_{1}, v_{2}, v_{3}, v_{4}, v_{5}, v_{6}, w_{1}, w_{2}\right\}$.

Sementara, himpunan garis dari graf dapat dituliskan sebagai berikut

$E=\left\{\begin{array}{l}v_{1} w_{1}, v_{2} w_{1}, v_{3} w_{1}, v_{4} w_{1}, v_{5} w_{1}, v_{6} w_{1} \\ v_{1} w_{2}, v_{2} w_{2}, v_{3} w_{2}, v_{4} w_{2}, v_{5} w_{2}, v_{6} w_{2}\end{array}\right\}$.

Dengan demikian, order $\mathrm{G}$ adalah $p(G)=7$, sedangkan size $\mathrm{G}$ adalah $q(G)=12$.

\section{Simulasi Pengiriman Susu ke Outlet}

Dari hasil pengambilan data diperoleh informasi bahwa susu dikirimkan secara acak ke outlet-outlet yang ada di daerah Malang dan Batu. Sehingga ada beberapa outlet yang terlewati untuk dikunjungi. Maka dari itu, untuk menangani masalah ini maka pengiriman susu dapat direpresentasikan dengan ketentuan sebagai berikut:

1. Truk A mengirimkan susu ke 2 outlet dengan kapasitas 1 ton dan 1 outlet dengan kapasitas 0,5 ton. 


\section{Truk B mengirimkan susu ke 2 outlet} dengan kapasitas 0,5 ton dan 2 outlet dengan kapasitas 1 ton.

Berdasarkan ketentuan pengiriman susu yang telah dibuat, maka simulasi graf dai gambar 5 dapat dibuat sebagai berikut.
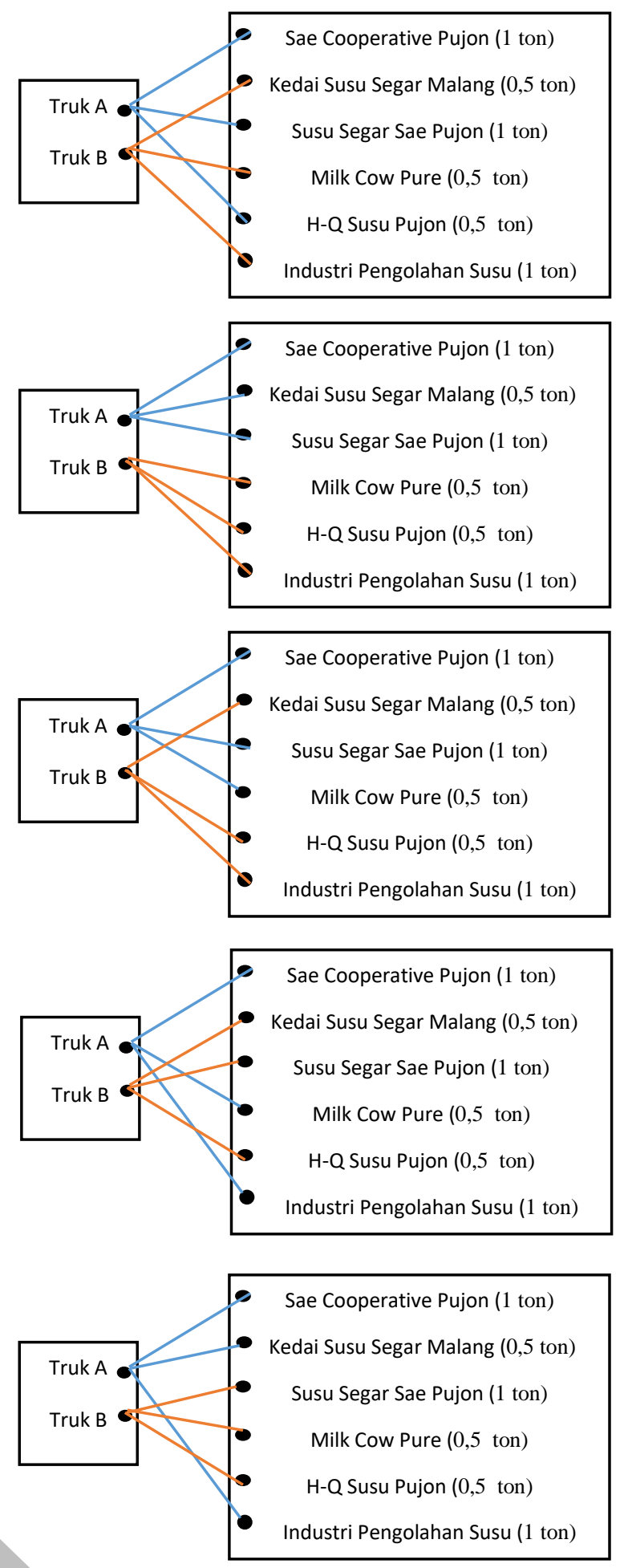
memiliki truk cadangan apabila terjadi masalah pada truk yang biasa digunakan untuk mengirim, sehingga proses pengiriman susu tersebut dapat dilaksanakan secara optimal.

\section{SIMPULAN}

Pada Kop SAE Pujon terdapat permasalahan mengenai proses pengiriman susu yang dipengaruhi oleh beberapa parameter antara lain banyaknya truk yang digunakan untuk mengirimkan susu dan outlet pengiriman susu.

Berdasarkan analisa hasil dan pembahasan diketahui bahwa Kop SAE Pujon memiliki 2 truk yang digunakan untuk mengirimkan susu pada 6 outlet di area Malang dan Batu. Dengan menggunakan aplikasi graf, terdapat 9 simulasi model pengiriman susu yang dapat dilakukan sesuai dengan outlet pengiriman yang telah ditentukan tanpa ada outlet yang terlewati.

\section{UCAPAN TERIMA KASIH}

Penulis megucapkan terimakasih kepada RISTEK DIKTI sebagai penyandang dana dalam penelitian ini yaitu Hibah Penelitian Dosen Pemula (PDP) pada tahun 2018.

\section{DAFTAR PUSTAKA}

Chartrand, G. dan L. Lesniak. 1986. Graf and Digraf 2nd Edition. California: Wadsworth, Inc.

Dinnullah, R. N. I \& T. Fayeldi. 2016. "Leontief Input-Output Method for The Fresh Milk Distribution Linkage Analysis". Jurnal Chauchy - Jurnal Matematika Murni dan Aplikasi. Vol. 4(3), pp:120-124.

Kusmira, M. Dan Taufiqurrochman. 2017. "Pemanfaatan Aplikasi Graf Pada Pembuatan Jalur Angkot 05 Tasikmalaya". Seminar Nasional Sains dan Teknologi 2017. Universitas Muhammadiyah Jakarta, 1-2 November 2017. Jakarta: Fakultas Teknik UMJ.

Listiyana, E. dan S. Hariyanto. 2008. "Sifat-Sifat Graf $\mathfrak{R}\left(2^{n}\right)$ ". Jurnal Matematika. Vol. 11(3), pp:111-114.

Miftahurrahmah. 2016. Aplikasi Teori Graf dalam Pengaturan Lampu Lalu Lintas. Skripsi. Makassar: UIN Alauddin Makassar.

Murugan, N. dan G. Esther. 2014. "Path Related Mean Cordial Grafs". Journal of Global Research in Mathematical Archives. Vol. 2(3), pp:74-86.

Roza, I., Narwen, dan Zulakmal. 2014. "Graf Garis (Line Graf) Dari Graf Siklus, Graf Lengkap dan Graf Bintang”. Jurnal Matematika Unand. Vol. 3(2), pp:1-4.

Sutrisno, D. A., K. Sri, M. A., Febrianto. 2015. "Studi Stabilitas Mutu Susu Segar Selama Pengangkutan Menggunakan Suhu Rendah yang Layak Secara Teknis Dan Finansial (Kajian Suhu Dan Lama Waktu Pendinginan)". Jurnal Teknologi Pertanian. Vol. 16(3), pp:207-212.

Wilson, R. J. 1996. Introduction to graph theory (Fourth Edition). USA: Longman, University of California. 
FIBONACCI : Jurnal Pendidikan Matematika dan Matematika

Volume 4 No.2 Bulan Desember Tahun 2018 